\title{
Residue-C effects on denitrification vary with soil depth
}

\author{
Marianne Kuntz ${ }^{\mathrm{a}, \mathrm{b}}$, Nicholas J. Morley ${ }^{\mathrm{a}}$, Paul D. Hallett ${ }^{\mathrm{a}}$, Christine Watson ${ }^{\mathrm{b}}$, \\ Elizabeth M. Baggs a, * \\ ${ }^{a}$ Institute of Biological and Environmental Sciences, University of Aberdeen, Cruickshank Building, St Machar Drive, Aberdeen, AB24 $3 U U$, UK \\ ${ }^{\mathrm{b}}$ Crop \& Soil Systems, SRUC, Craibstone Estate, Aberdeen, AB21 9YA, UK
}

\section{A R T I C L E I N F O}

\section{Article history:}

Received 27 May 2016

Received in revised form

6 September 2016

Accepted 18 September 2016

\section{Keywords:}

Nitrous oxide

Dinitrogen

Stable isotope

Soil depth

Residue

Carbon

\begin{abstract}
A B S T R A C T
A stable isotope $\left({ }^{13} \mathrm{C}\right.$-residue, ${ }^{15} \mathrm{~N}-\mathrm{NO}_{3}^{-}$fertiliser $)$approach combined with measurements of soil pore space gas concentrations was used to investigate spatial and temporal mechanisms of residue carbon (C) affecting denitrification. Whilst relationships between residue addition and $\mathrm{N}_{2} \mathrm{O}$ fluxes have previously been well characterised, the influence of residues on production and reduction of $\mathrm{N}_{2} \mathrm{O}$ at depth is less well understood. Here we investigated the relationship between residue- ${ }^{13} \mathrm{C}$ addition $(0,1$ and $2 \mathrm{mg} \mathrm{C}$ $\mathrm{g}^{-1}$ soil) and denitrification $\left({ }^{15} \mathrm{~N}-\mathrm{N}_{2} \mathrm{O}\right.$ and ${ }^{15} \mathrm{~N}-\mathrm{N}_{2}$ production) at 2,5 and $8 \mathrm{~cm}$ soil depths and also fluxes from the soil surface. Hydrophobic probes that equilibrate with the soil gas phase were used to extract gases at soil depth, followed by analysis for ${ }^{15} \mathrm{~N}-\mathrm{N}_{2} \mathrm{O},{ }^{15} \mathrm{~N}-\mathrm{N}_{2},{ }^{13} \mathrm{C}-\mathrm{CO}_{2}$ and $\mathrm{O}_{2}$ concentrations. ${ }^{15} \mathrm{~N}-\mathrm{N}_{2} \mathrm{O}$ and $\mathrm{CO}_{2}$ surface fluxes peaked one day after ${ }^{14} \mathrm{NH}_{4}^{15} \mathrm{NO}_{3}$ application ( $1 \mathrm{mg} \mathrm{N} \mathrm{g}^{-1}$ soil), with residue application resulting in a more than 20 -fold greater ${ }^{15} \mathrm{~N}-\mathrm{N}_{2} \mathrm{O}$ emission rate compared to the non-amended control. Eight days after $\mathrm{N}$ application ${ }^{15} \mathrm{~N}-\mathrm{N}_{2} \mathrm{O}$ pore space concentrations had significantly increased 20-fold at $8 \mathrm{~cm}$ depth below the residue layer compared to no residue application. However, simultaneous increases in ${ }^{15} \mathrm{~N}-\mathrm{N}_{2}$ surface fluxes and profile concentrations showed efficient reduction of the $\mathrm{N}_{2} \mathrm{O}$ at shallow depth (3-10 cm depth) resulting in surface emission of $\mathrm{N}_{2}$ rather than $\mathrm{N}_{2} \mathrm{O}$. Our results have implications for management to lower emissions as denitrifier activity at greater depth, and the greater reduction of $\mathrm{N}_{2} \mathrm{O}$ to $\mathrm{N}_{2}$, appeared to be indirectly driven by residue addition via the depletion of $\mathrm{O}_{2}$ during aerobic heterotrophic respiration in the surface layer. In contrast, net surface fluxes of $\mathrm{N}_{2} \mathrm{O}$ were more directly related to the residue addition through substrate provision for denitrification.
\end{abstract}

(C) 2016 The Authors. Published by Elsevier Ltd. This is an open access article under the CC BY license (http://creativecommons.org/licenses/by/4.0/).

\section{Introduction}

Emissions of the potent greenhouse gas $\mathrm{N}_{2} \mathrm{O}$ generally increase following application of organic residues to agricultural soils (Chen et al., 2013; Muhammad et al., 2010). Residues supply C and $\mathrm{N}$ to the soil, enhancing mineralisation and stimulating heterotrophic microbial activity. Whereas mineralisation supplies ammonium for the first step of nitrification, the associated increased respiration may lower concentrations of soil $\mathrm{O}_{2}$ to create conditions conducive for denitrification (Baggs et al., 2000; Huang et al., 2004; Li et al., 2016). Despite the large body of literature on residue quality and quantity effects on net emissions of the greenhouse gas $\mathrm{N}_{2} \mathrm{O}$, relatively little is known on the role of residue- $\mathrm{C}$ in the reduction of

\footnotetext{
* Corresponding author.

E-mail addresses: marianne.kuntz@abdn.ac.uk (M. Kuntz),n.morley@abdn.ac.uk (N.J. Morley), paul.hallett@abdn.ac.uk (P.D. Hallett), christine.watson@sruc.ac.uk (C. Watson), e.baggs@abdn.ac.uk (E.M. Baggs).
}

$\mathrm{N}_{2} \mathrm{O}$ to $\mathrm{N}_{2}$ during denitrification, especially with regard to depth within arable topsoil. A greater understanding of the relative importance of indirect and direct residue effects on $\mathrm{N}_{2} \mathrm{O}$ reduction could make important contributions to the design of management strategies that target decreased emission of $\mathrm{N}_{2} \mathrm{O}$ from arable soil.

The quantity and chemical composition of residues has been demonstrated to have a large impact on $\mathrm{N}_{2} \mathrm{O}$ emissions following addition to agricultural soils (Chen et al., 2013; Miller et al., 2012; Thangarajan et al., 2013). Low C:N ratio residues have been shown to increase net $\mathrm{N}_{2} \mathrm{O}$ emissions compared to high $\mathrm{C}$ : $\mathrm{N}$ ratio residues (Chen et al., 2013). With low C: $\mathrm{N}$ ratio residues microbial activity and growth are stimulated and $\mathrm{N}$ availability can subsequently increase through increased mineralisation and nitrification of residue $\mathrm{N}$ and soil organic matter $\mathrm{N}$. The resulting available nitrate can be utilized during denitrification and can also regulate the reduction of $\mathrm{N}_{2} \mathrm{O}$ to $\mathrm{N}_{2}$ especially when $\mathrm{C}$ availability is low (Miller et al., 2008; Senbayram et al., 2012). Individual C compounds have been shown to exert different influences on the $\mathrm{N}_{2} \mathrm{O} /\left(\mathrm{N}_{2} \mathrm{O}+\mathrm{N}_{2}\right)$ 
product ratio of denitrification (Morley et al., 2014), and so the chemical composition of the residue has a direct influence on the product ratio and net $\mathrm{N}_{2} \mathrm{O}$ emission (Miller et al., 2008; Gillam et al., 2008) with, for example, residue polyphenol and lignin contents being negatively related to net $\mathrm{N}_{2} \mathrm{O}$ emissions (Frimpong and Baggs, 2010; Millar and Baggs, 2005, 2004).

In order to understand the effects of residue on nitrate reduction we however need to dig a bit deeper than just measuring surface fluxes of $\mathrm{N}_{2} \mathrm{O}$. Considerable microbial activity occurs below the soil surface and surface fluxes can be a poor predictor of denitrification dynamics especially when considering the complete denitrification pathway (Ball, 2013). The decrease in $\mathrm{O}_{2}$ concentrations with depth, emphasised by impeded gas diffusivity at high water-filled pore space, can drive both the production and reduction of $\mathrm{N}_{2} \mathrm{O}$ (Jarecke et al., 2016; McCarty et al., 1999). Jahangir et al. (2012) explored denitrification over a range of soil depths following substrate amendment, but the amendments were mobile liquids (glucose or DOC) so would not create a substrate hotspot and the diffusion of secondary compounds that would be found for solid residue. The oxygen status of arable topsoil can however, be altered as a consequence of organic inputs through increased heterotrophic respiration and $\mathrm{C} / \mathrm{N}$ mineralisation. Zhu et al. (2015) showed that $\mathrm{O}_{2}$ depletion below a layer of decomposing manure can alter net $\mathrm{N}_{2} \mathrm{O}$ surface emissions most likely by creating conditions conducive to $\mathrm{N}_{2} \mathrm{O}$ formation in denitrification. On a much smaller scale, but following a similar rationale, Højberg et al. (1994) found that the consumption of $\mathrm{O}_{2}$ by mineralisation of residue- $\mathrm{C}$ on a soil aggregate surface can enhance the production and reduction of $\mathrm{N}_{2} \mathrm{O}$ in the centre of an aggregate.

Residue addition can both directly drive denitrification via quality and quantity of input but also indirectly through oxygen depletion, influencing the magnitude of net $\mathrm{N}_{2} \mathrm{O}$ surface fluxes. However, the effects of residue- $C$ addition on the spatial location of denitrifier $\mathrm{N}_{2} \mathrm{O}$ production and reduction hotspots have yet to be addressed. This study was performed to determine the influence of residue- $\mathrm{C}$ in driving production and reduction of $\mathrm{N}_{2} \mathrm{O}$ within and throughout an arable topsoil, following surface application of two rates of ${ }^{13} \mathrm{C}$-labelled barley residue. It combined surface flux measurements of ${ }^{15} \mathrm{~N}-\mathrm{N}_{2} \mathrm{O}$ and ${ }^{15} \mathrm{~N}-\mathrm{N}_{2}$ and residue- and SOM-derived $\mathrm{CO}_{2}$ with the same measurements taken at 3 depths. We hypothesised i) a positive relationship of $\mathrm{N}_{2} \mathrm{O}$ and $\mathrm{N}_{2}$ with residue-derived ${ }^{13} \mathrm{C}-\mathrm{CO}_{2}$ and ii) greater reduction of $\mathrm{N}_{2} \mathrm{O}$ to $\mathrm{N}_{2}$ at greater depth within the soil core related to decreasing $\mathrm{O}_{2}$ availability.

\section{Materials and methods}

\subsection{Experimental design and set-up}

To enable gas sampling at depth a novel microcosm setup was developed (Fig. 1). It consisted of a $5.3 \mathrm{~cm}$ diameter $\mathrm{x} 10 \mathrm{~cm}$ depth soil core with a sectioned gas permeable sampling tube inserted into the centre. The sampling tube was manufactured from sections of stainless steel tube $(1.54 \mathrm{~cm}$ inner diameter) and hydrophobic, gas permeable tubing $(1.4 \mathrm{~cm}$ inner diameter $\mathrm{x} 1.6 \mathrm{~cm}$ outer diameter, ePTFE at a density of $0.9 \mathrm{~g} \mathrm{~cm}^{-3}$, fibre porosity of $60 \%$, Markel Corporation, Plymouth Meeting, USA). A $1 \mathrm{~cm}$ section of the gas permeable tube was fixed at depths of either $1.1-2.1 \mathrm{~cm}$, $4.4-5.4 \mathrm{~cm}$ or $7.8-8.8 \mathrm{~cm}$ with sections of stainless steel at either end to create a $10 \mathrm{~cm}$ length tube. For simplicity the sampling depths of the soil gas phase are referred to as $2 \mathrm{~cm}, 5 \mathrm{~cm}$ and $8 \mathrm{~cm}$. The top of the tube was permanently sealed with a Suba seal septum (Suba Seal no. 29), permitting periodical gas sampling with a needle and syringe. The equilibration time of the soil sampler with the atmosphere was below $80 \mathrm{~s}$ as tested by measuring atmospheric $\mathrm{O}_{2}$ diffusion into the tube.
The soil was field moist at $65 \%$ water-filled pore space (WFPS) after packing around the gas sampling tube to a bulk density of $1.2 \mathrm{~g}$ soil $\mathrm{cm}^{-3}$. This resembled field conditions at the site and resulted in $213 \mathrm{~g}$ soil per tube. In order to obtain the same bulk density throughout the core, packing was done in six steps of soil addition and compaction. A platen that covered the entire area of the soil surface, with a hole cut in the centre, was used to ensure even packing.

The soil was sampled from NPK fertilised pasture and hay plots from the long-term fertilisation experiment at Woodlands Field, Craibstone Estate, Aberdeen in May 2014. Field moist soil was bulked, mixed and sieved to $\leq 2 \mathrm{~mm}$ and stored at $4{ }^{\circ} \mathrm{C}$ for approximately two weeks before the experiment. The soil is a loamy sand with $68 \%$ sand, $24 \%$ silt and $8 \%$ clay, an average $\mathrm{pH}_{\mathrm{H} 2 \mathrm{O}}$ of 5.5 and a total organic carbon content of $5.5 \%$. The soil had received fertiliser rates of $80 \mathrm{~kg} \mathrm{~N} \mathrm{ha}^{-1}$ as $\mathrm{NH}_{4} \mathrm{NO}_{3}, 26 \mathrm{~kg} \mathrm{P}^{-1}$ as triple superphosphate and $58 \mathrm{~kg} \mathrm{~K} \mathrm{ha}^{-1}$ as muriate of potash in early March 2014. The soil contained $1.7 \mu \mathrm{g} \mathrm{NH}_{4}^{+}-\mathrm{N} \mathrm{g}^{-1}$ soil, $39.3 \mu \mathrm{g} \mathrm{NO}_{3}^{-}-$ $\mathrm{N} \mathrm{g}^{-1}$ soil and $81.7 \mu \mathrm{g} \mathrm{C} \mathrm{g}^{-1}$ soil dissolved organic carbon at the beginning of the experiment.

Ground barley residue ( $<2 \mathrm{~mm}$ particle size, see below) was added to the soil at $0 \mathrm{mg}, 1 \mathrm{mg}$ or $2 \mathrm{mg} \mathrm{C} \mathrm{g}^{-1}$ soil. The $C$ addition was calculated for the total soil content of the soil core, but addition was concentrated to the top $3 \mathrm{~cm}$ of the soil core to mimic superficial residue incorporation. Each combination of sampling depth with residue treatment was replicated 4 times ( 3 residue treatments $\mathrm{x} 3$ depths $x 4$ replicates) resulting in 4 replicates per residue treatment for the soil gas phase at each of the 3 depths but, as the headspace flux was determined for all soil cores, independent of the gas sampler inserted, 12 replicates per treatment for the surface gas fluxes. Additional 9 soil cores (3 residue treatments $\mathrm{x} 3$ replicates) were set up for destructive sampling of the soil $\mathrm{N}$ and $\mathrm{C}$ pools (described in Section 2.4) on days $0,1,3,8,15$ while on the last day of the experiment, day 23 , a triplicate of the gas sampling cores were used.

To provide conditions favourable for denitrification in this soil (Ball, 2013) the water content was adjusted to 85\% WFPS by pipetting $\mathrm{N}$ fertiliser solution onto the soil surface of all soil cores. The $\mathrm{N}$ fertiliser addition of $4.77 \mathrm{ml}$ of $\mathrm{NH}_{4}^{15} \mathrm{NO}_{3}$ solution ( $25 \mathrm{atom} \%$ ${ }^{15} \mathrm{~N}$ ) to the soil surface marked the beginning of the experiment. The application rate corresponded to $120 \mathrm{~kg} \mathrm{~N} \mathrm{ha}^{-1}$ or $0.99 \mathrm{mg} \mathrm{N}$ $\mathrm{g}^{-1}$ soil, therefore $210.9 \mathrm{mg} \mathrm{N}$ were added to each soil core. The soil cores were kept on the lab bench and WFPS was maintained by water addition, when required, on a mass basis.

\section{2. ${ }^{13} \mathrm{C}$-labelling of barley plant material}

Barley (Hordeum vulgare, ssp. Belgravia) was grown at $30^{\circ} \mathrm{C}$ in the glasshouse in February 2014 for a period of 52 days prior to ${ }^{13} \mathrm{C}$ labelling. Two trays of approximately 40 plants were transferred to a gas-tight glove box and enriched with ${ }^{13} \mathrm{C}_{-} \mathrm{CO}_{2}$. Enrichment of the atmosphere was done by volatilizing 99 atom\% $\mathrm{NaH}^{13} \mathrm{CO}_{3}$ using $0.1 \mathrm{M} \mathrm{HCl}$ solution on a magnetic stirrer within the glove box. After $7 \mathrm{~h}$ the above-ground plant material was cut and immediately dried at $40{ }^{\circ} \mathrm{C}$ until no further weight loss occurred. It was milled to $<2 \mathrm{~mm}$ particle size using a hammer mill. The milled and bulked plant material had a carbon content of $44.2 \%$ and a $\mathrm{C} / \mathrm{N}$ ratio of 10.8 . The bulked plant material was 1.98 atom\% excess ${ }^{13} \mathrm{C}$ as determined on a 20/20 isotope ratio mass spectrometer (Sercon Ltd, Crewe, UK).

Due to using pulse labelling, the barley plant material was not homogeneously enriched in ${ }^{13} \mathrm{C}$ and thus fractionated into the hotwater soluble $\mathrm{C}$ content and the non-soluble residue. This was done by extracting the plant material for $30 \mathrm{~min}$ at $60{ }^{\circ} \mathrm{C}$ on a magnetic stirrer and filtering it through a $20 \mu \mathrm{m}$ membrane (Soong et al., 2014). The water soluble fraction was freeze-dried, the residue 

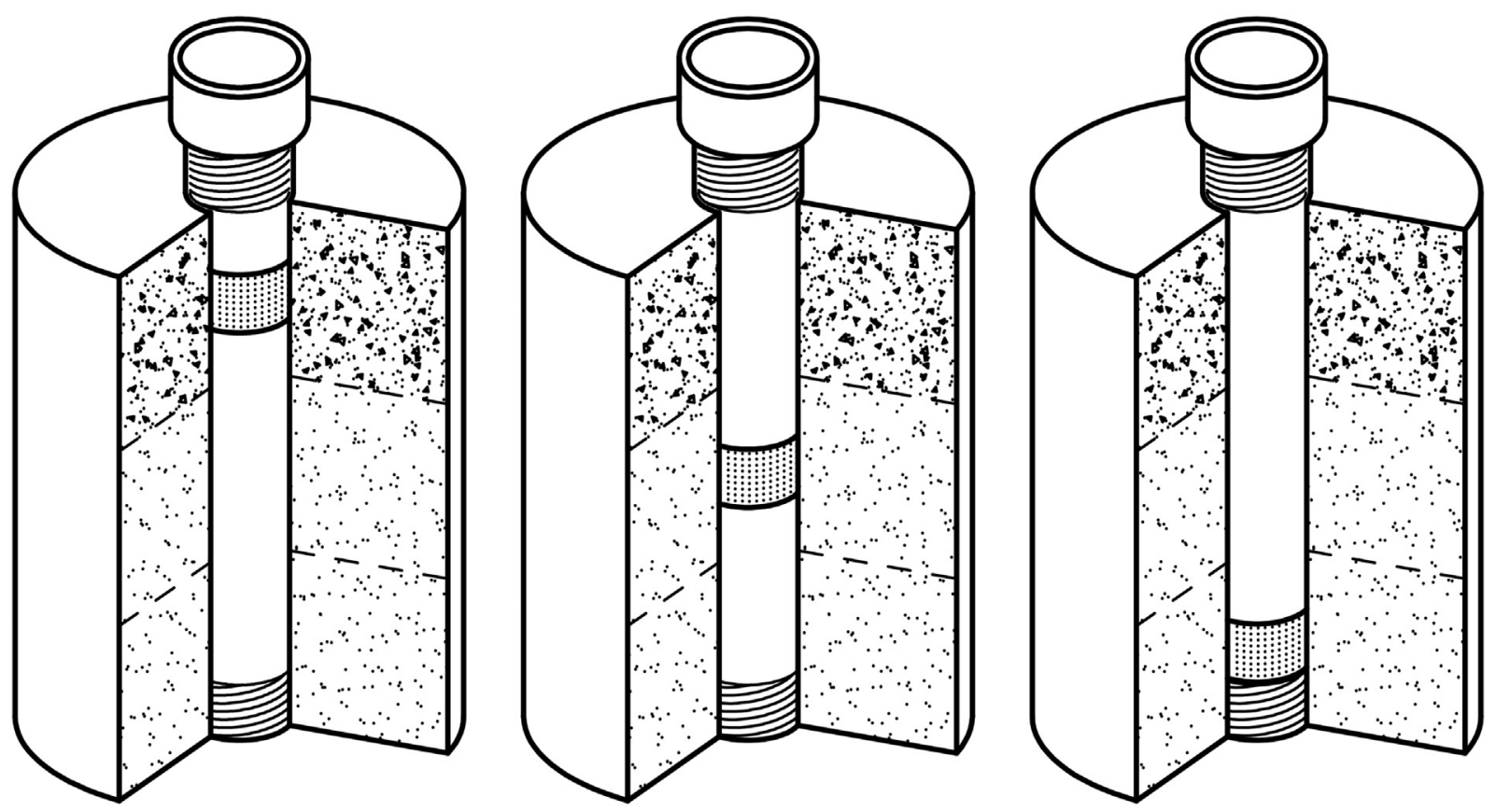

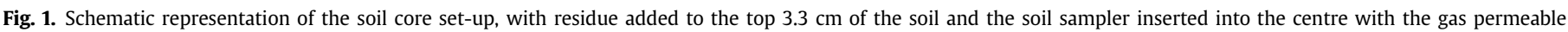
membrane replacing the steel tube at 2,5 or $8 \mathrm{~cm}$ depth.

oven-dried at $40{ }^{\circ} \mathrm{C}$ and both isotopically characterised by isotope ratio mass spectrometry. Of the total C $79.15 \%$ and $20.85 \%$ was recovered in the residue and the hot-water extract, respectively, with isotopic enrichments of 1.60 atom\% excess ${ }^{13} \mathrm{C}$ and 3.47 atom\% excess ${ }^{13} \mathrm{C}$, respectively.

\subsection{Gas sampling and analyses}

On days $0,1,3,8,15$ and 23 the soil cores were placed in $1 \mathrm{~L}$ Kilner jars fitted with two-way valves in the lid for $180 \mathrm{~min}$. Samples for initial concentrations of $\mathrm{N}_{2} \mathrm{O}$ and $\mathrm{CO}_{2}$ were taken immediately after jar closure and after a period of $180 \mathrm{~min}$ headspace gas was sampled. Preliminary tests showed linear accumulation of $\mathrm{N}_{2} \mathrm{O}$ and $\mathrm{CO}_{2}$ during that period of time. Using a gas-tight syringe, $5 \mathrm{ml}$ of gas was taken and stored in pre-evacuated $3 \mathrm{ml}$ LabCo exetainer vials for analysis for $\mathrm{CO}_{2}$ and $\mathrm{N}_{2} \mathrm{O}$ by gas chromatography. Furthermore, a $15 \mathrm{ml}$ headspace sample was taken and stored in pre-evacuated $12 \mathrm{ml}$ LabCo gas vials for ${ }^{13} \mathrm{C}-\mathrm{CO}_{2}$ analysis as well as $150 \mathrm{ml}$ of gas stored in He-flushed, pre-evacuated, $120 \mathrm{ml}$ amber bottles prior to analysis for ${ }^{15} \mathrm{~N}-\mathrm{N}_{2} \mathrm{O}$ and ${ }^{15} \mathrm{~N}-\mathrm{N}_{2}$ concentrations on the isotope ratio mass spectrometer. The cores were removed from the Kilner jars after headspace sampling.

Before each sampling for the soil gas phase from the soil sampler, an $\mathrm{O}_{2}$ fixed needle type sensor (OXF500PT, PyroScience, Munich, Germany) coupled to an oxygen meter (FireStingO2, PyroScience, Munich, Germany) was inserted through the surface facing septum to obtain $\mathrm{O}_{2}$ concentrations representing the pore space of the bulk soil at 2, 5 and $8 \mathrm{~cm}$ depth. The $\mathrm{O}_{2}$ sensor was calibrated with two points, i.e. $0 \% \mathrm{O}_{2}$ in $\mathrm{He}$ as well as atmospheric $\mathrm{O}_{2}$.

The soil gas phase from the depths of 2,5 and $8 \mathrm{~cm}$ was sampled directly into exetainer vials using a three-way valve to prevent injecting the needle more than once. One $\mathrm{ml}$ of gas was sampled into $3 \mathrm{ml} \mathrm{He}$-filled vials for quantification of $\mathrm{CO}_{2}$ and $\mathrm{N}_{2} \mathrm{O}$ using gas chromatography, and $2 \mathrm{ml}$ were removed each for ${ }^{15} \mathrm{~N}$ and ${ }^{13} \mathrm{C}$ analysis and transferred to He-filled $12 \mathrm{ml}$ exetainer vials. In total, $5 \mathrm{ml}$ of gas were removed from the soil gas sampler (12 ml volume) on each sampling occasion in the monitoring sequence.

Concentrations of $\mathrm{CO}_{2}$ and $\mathrm{N}_{2} \mathrm{O}$ were analysed on a gas chromatograph (GC) (Agilent 6890, Santa Clara, USA) equipped with an electron capture detector at $300{ }^{\circ} \mathrm{C}$ and a methaniser and flame ionisation detector at $250{ }^{\circ} \mathrm{C}$. Gases were separated on a Haysep Q column at $45{ }^{\circ} \mathrm{C}$, the sample volume injected by the autosampler (HT29748, HTA, Italy) was $500 \mu$ l. The GC was calibrated for $\mathrm{CO}_{2}$ and $\mathrm{N}_{2} \mathrm{O}$ using standards of known concentrations. Isotope ratios for $\mathrm{N}_{2} \mathrm{O}, \mathrm{N}_{2}$ and $\mathrm{CO}_{2}$ were determined on the isotope ratio mass spectrometer after cryofocusing the gas sample in an ANCA TGII trace gas preparation module. The minimum concentration of $\mathrm{N}_{2} \mathrm{O}$ in the exetainer vials sampled from 5 and $8 \mathrm{~cm}$ depth after dilution in He was 0.5 ppmv. However, in the case of gas samples obtained from $2 \mathrm{~cm}$ depth, the concentrations were not sufficient to reliably quantify ${ }^{15} \mathrm{~N}$ enrichment in both $\mathrm{N}_{2} \mathrm{O}$ and $\mathrm{N}_{2}$ and were therefore not presented. The natural abundance in air was used as a reference for $\mathrm{N}$ isotope determination and in $12 \mathrm{ml}$ exetainer vials the average atom $\%{ }^{15} \mathrm{~N}$ value of atmospheric concentrations of $\mathrm{N}_{2} \mathrm{O}$ was 0.3735 atom $\%{ }^{15} \mathrm{~N}$ with a standard deviation of 0.0304 atom $\%{ }^{15} \mathrm{~N}$. Acidified $\mathrm{NaCO}_{3}$ calibrated versus the international standard (IAEA NBS-18) was used as a reference for carbon isotope determination.

\subsection{Biochemical soil analyses}

Soil samples were taken at three depth intervals $(0-3.3 \mathrm{~cm}$, $3.3-6.6 \mathrm{~cm}$ and $6.6-10 \mathrm{~cm}$ from the core surface) by inserting a soil corer of $10 \mathrm{~mm}$ ID into the respective depths, first to $3.3 \mathrm{~cm}$, then to 6.6 and $10 \mathrm{~cm}$ depth, and making a composite sample of at least $40 \mathrm{~g}$ fresh soil from each depth. For the sake of simplicity, the depths are referred to as $2 \mathrm{~cm}, 5 \mathrm{~cm}$ and $8 \mathrm{~cm}$ depth when describing extraction data and match those of the gas samples.

Nitrate concentrations were measured in $1 \mathrm{M} \mathrm{KCl}$ soil extracts which had been shaken for $1 \mathrm{~h}$ and subsequently filtered (Whatman No.1). Extracts were stored at $-18{ }^{\circ} \mathrm{C}$ until colorimetric analysis by a flow injection analyser (FIAstar 5000 Analyser, Foss Tecator, Hillerød, Denmark). To analyse for ${ }^{15} \mathrm{~N}_{-} \mathrm{NO}_{3}$ the diffusion method as described by Stark and Hart (1996) was used. The ${ }^{15} \mathrm{~N}$ - 
enrichment of $\mathrm{NO}_{3}^{-}$was determined on the isotope ratio mass spectrometer.

Standard chloroform fumigation extraction procedures were followed to determine microbial biomass carbon (Vance et al., 1987). A $5 \mathrm{~g}$ subsample of fresh soil was extracted or exposed to chloroform saturated air for $24 \mathrm{~h}$ before extraction with $0.5 \mathrm{M}$ $\mathrm{K}_{2} \mathrm{SO}_{4}$. The extracts were analysed for total organic carbon (LABTOC analyser, Pollution \& Process Monitoring Ltd., Sevenoaks, UK). Total organic carbon extracted from non-fumigated soil is referred to as dissolved organic C (DOC). Microbial biomass carbon was calculated as the difference between fumigated and non-fumigated soil multiplied by a correction factor of 0.45 (Joergensen, 1996).

\subsection{Calculations and statistical analyses}

The proportion of the residue-derived $\mathrm{CO}_{2}$ flux as the fraction of the ${ }^{12+13} \mathrm{C}_{-}-\mathrm{CO}_{2}$ fluxes and the soil gas phase was calculated according to,

$$
\begin{aligned}
\mathrm{P}_{\text {barley }}= & \left(\text { atom } \%{ }^{13} \mathrm{C}_{\text {sample }}-\text { atom } \%{ }^{13} \mathrm{C}_{\mathrm{SOM}}\right) / \\
& \left(\text { atom } \%{ }^{13} \mathrm{C}_{\text {barley }}-\text { atom } \%{ }^{13} \mathrm{C}_{\mathrm{SOM}}\right)
\end{aligned}
$$

where $\mathrm{P}_{\text {barley }}$ is the proportion of the total $\mathrm{CO}_{2}$ in flux and soil gas that was barley derived, atom\% ${ }^{13} \mathrm{C}_{\text {sample represents the }}{ }^{13} \mathrm{C}$ of the $\mathrm{CO}_{2}$ sample, atom\% ${ }^{13} \mathrm{C}_{\mathrm{SOM}}$ is the average ${ }^{13} \mathrm{C}-\mathrm{CO}_{2}$ of the soil that received no barley $\mathrm{C}$ and atom $\%{ }^{13} \mathrm{C}_{\text {barley }}$ is the atom $\%{ }^{13} \mathrm{C}$ measured in the hot-water extract of the barley plant material as this most likely represented the utilised fraction of residue-C (Trinsoutrot et al., 2000).

The proportion of $\mathrm{N}$ gas (total denitrification products in the following referred to as ${ }^{15} \mathrm{~N}-\mathrm{N}_{2} \mathrm{O}$ and ${ }^{15} \mathrm{~N}-\mathrm{N}_{2}$ ) in the headspace or samplers that was derived from the applied ${ }^{15} \mathrm{~N}-\mathrm{NO}_{3}^{-}$and ${ }^{14} \mathrm{~N}-\mathrm{NO}_{3}^{-}$ was calculated accounting for the isotopic enrichment of the $\mathrm{NO}_{3}^{-}$ pool according to

$$
\begin{aligned}
& \text { Fraction nitrate derived } \mathrm{N}_{2} \mathrm{O} \text { or } \mathrm{N}_{2} \\
& =\text { atom } \%{ }^{15} \mathrm{~N} \text { excess } \mathrm{N}_{2} \mathrm{O} \text { or } \mathrm{N}_{2} / \text { atom } \%{ }^{15} \mathrm{~N} \text { excess } \mathrm{NO}_{3}^{-},
\end{aligned}
$$

where atom $\%{ }^{15} \mathrm{~N}$ excess for gas samples was calculated by subtraction of 14/15 $\mathrm{N}$ ratios obtained from headspaces of triplicate non- ${ }^{15} \mathrm{~N}$ enriched control soils and for the $\mathrm{NO}_{3}^{-}$pool by subtracting natural abundance of ${ }^{15} \mathrm{~N}$ from the atom \% value for $\mathrm{NO}_{3}^{-}$derived by the diffusion method.

Cumulative values for gaseous emissions were calculated from measured fluxes using the trapezoidal method.

All statistical analyses were performed using $\mathrm{R}$ ( $\mathrm{R}$ Development Core Team, 2015). Effects of the sampling day and barley $C$ amendment rate on fluxes and concentrations of $\mathrm{N}_{2} \mathrm{O}, \mathrm{N}_{2}$ and $\mathrm{CO}_{2}$ were compared using either a linear model or a linear mixed model accounting for repeated measurement if that improved the model fit based on model comparison. Regression analysis was performed using the same approach. Variables were log-transformed to achieve normal distribution and homogeneity of variances where necessary.

\section{Results}

\subsection{Cumulative gaseous emissions}

The total $\mathrm{CO}_{2}$ emitted over 23 days more than tripled with an amendment of $2 \mathrm{mg}$ residue- $\mathrm{C}$ compared to non- $\mathrm{C}$ amended soil $(P<0.001)$ (Table 1$)$. Overall, significantly more ${ }^{14+15} \mathrm{~N}-\mathrm{N}_{2} \mathrm{O}$ and
${ }^{15} \mathrm{~N}-\mathrm{N}_{2} \mathrm{O}$ was emitted from the surface of both residue amended soils compared to the non- $C$ amended control $(P<0.01)$ (Table 1$)$ but emissions between the two residue- $C$ treatments did not differ. Fertiliser nitrate derived ${ }^{15} \mathrm{~N}-\mathrm{N}_{2} \mathrm{O}$ accounted for $45.4 \%, 81.8 \%$ and $73.5 \%$ of total $\mathrm{N}_{2} \mathrm{O}$ surface emission in the $0 \mathrm{mg}, 1 \mathrm{mg}$ and $2 \mathrm{mg}$ residue- $\mathrm{C}$ treatments, respectively. Compared to the non- $\mathrm{C}$ amended control, soils that received residue- $C$ emitted significantly more ${ }^{15} \mathrm{~N}-\mathrm{N}_{2}$ over 23 days $(P<0.05)$ with no significant difference between amendment rates. The ${ }^{15} \mathrm{~N}-\left(\mathrm{N}_{2} \mathrm{O} /\left(\mathrm{N}_{2} \mathrm{O}+\mathrm{N}_{2}\right)\right)$ ratio of the surface emissions over 23 days was not significantly different between residue treatments, but was greater than the ratio calculated for the non- $\mathrm{C}$ amended control (Table 1 ).

\section{2. $\mathrm{CO}_{2}$ fluxes and concentrations at different depths}

The ${ }^{12+13} \mathrm{C}-\mathrm{CO}_{2}$ fluxes peaked one day following $\mathrm{N}$ fertilisation and residue amendment. This was similar for both residue- $\mathrm{C}$ treatments and the control where no $\mathrm{C}$ but only $\mathrm{N}$ had been added (Fig. 2A). The response of residue-derived ${ }^{13} \mathrm{C}_{-}-\mathrm{CO}_{2}$ to residue treatment was dependent on the day of measurement (significant interaction between Day and C, $P<0.001$ ) (Fig. 2D). For the $2 \mathrm{mg}$ residue- $C$ amendment we observed greatest residue-derived surface fluxes of $453 \mu \mathrm{g}{ }^{13} \mathrm{C}-\mathrm{CO}_{2}$ core ${ }^{-1} \mathrm{~h}^{-1}$ immediately after application of $\mathrm{N}$ and residue, followed by a steep decline in surface fluxes between days 0 and 3 . Rates still decreased steadily after day 3 until the end of the experiment, but the differences between days were much smaller.

Except for day 0 when residue-derived $\mathrm{C}$ accounted for $64 \%$ and $32 \%$ of the total $\mathrm{CO}_{2}$ flux in the 2 and $1 \mathrm{mg}$ residue- $\mathrm{C}$ treatments, respectively, the fraction of residue-derived $\mathrm{CO}_{2}$ was similar between soils amended with either 1 or $2 \mathrm{mg}$ residue-C. It decreased from $~ 30 \%$ on day 1 to about $10 \%$ at the end of the experiment, and from day 3 SOM-C mineralisation was the dominating $C$ source for microbial respiration.

At $5 \mathrm{~cm}$ depth the effect of residue amendment rate on ${ }^{12+13} \mathrm{C}$ $\mathrm{CO}_{2}$ concentrations differed between days $(P<0.01)$. In soils amended with $1 \mathrm{mg}$ residue- $\mathrm{C},{ }^{12+13} \mathrm{C}-\mathrm{CO}_{2}$ concentrations on days 3,8 and 23 exceeded the concentrations in control soils that did not receive residue. ${ }^{12+13} \mathrm{C}-\mathrm{CO}_{2}$ concentrations in the $2 \mathrm{mg}$ residue- $\mathrm{C}$ treated soil were similar to the control on all days except day 0 (Fig. 2B). At $8 \mathrm{~cm}$ depth ${ }^{12+13} \mathrm{C}^{2}-\mathrm{CO}_{2}$ concentrations were significantly different between days $(P<0.001)$ but not between $C$ treatments. Significantly higher concentrations were measured on all days compared to day 0 with a steady increase from day 1-15 and a significant decrease in ${ }^{12+13} \mathrm{C}^{-} \mathrm{CO}_{2}$ concentrations from day 15-23 (Fig. 2C).

At both soil depths the \% residue-derived $\mathrm{CO}_{2}$ of the total $\mathrm{CO}_{2}$ concentration was greatest on day 0 (data not shown). Immediately after application of $1 \mathrm{mg}$ residue-C, the \% residue-derived $\mathrm{CO}_{2}$ was $20 \%$ and $9 \%$ of the total $\mathrm{CO}_{2}$ concentration at 5 and $8 \mathrm{~cm}$ depth, respectively. The contribution of ${ }^{13} \mathrm{C}-\mathrm{CO}_{2}$ to the total $\mathrm{CO}_{2}$ in the $2 \mathrm{mg}$ residue- $\mathrm{C}$ treatment was $48 \%$ and $11 \%$ at 5 and $8 \mathrm{~cm}$ depth, respectively. By day 3 , the \% residue-derived $\mathrm{CO}_{2}$ had decreased to below $10 \%$ of the total $\mathrm{CO}_{2}$ concentration at both soil depths for both residue amendment rates.

\section{3. $\mathrm{N}_{2} \mathrm{O}$ fluxes and concentrations at different soil depths}

Residue amendment greatly affected headspace $\mathrm{N}_{2} \mathrm{O}$ emission The ${ }^{15} \mathrm{~N}-\mathrm{N}_{2} \mathrm{O}$ surface fluxes peaked on day 1 when soil amended with $1 \mathrm{mg}$ residue-C emitted significantly more ${ }^{15} \mathrm{~N}-\mathrm{N}_{2} \mathrm{O}(21.31 \mu \mathrm{g}$ ${ }^{15} \mathrm{~N}-\mathrm{N}_{2} \mathrm{O}$ core $\left.\mathrm{cos}^{-1} \mathrm{~h}^{-1}\right)$ than soils that received no $\mathrm{C}\left(0.14 \mu \mathrm{g}{ }^{15} \mathrm{~N}-\mathrm{N}_{2} \mathrm{O}\right.$ core $^{-1} \mathrm{~h}^{-1}$ ) or $2 \mathrm{mg}$ residue-C $\left(7.31 \mu \mathrm{g}{ }^{15} \mathrm{~N}-\mathrm{N}_{2} \mathrm{O}\right.$ core $\left.^{-1} \mathrm{~h}^{-1}\right)$ (significant interaction between Day and $C, P<0.001$ ) (Fig. $3 \mathrm{~A}$ ). ${ }^{15} \mathrm{~N}-$ $\mathrm{N}_{2} \mathrm{O}$ fluxes did not differ between residue treatments on any other 
Table 1

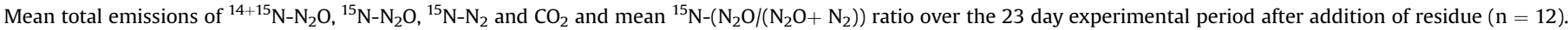

\begin{tabular}{|c|c|c|c|c|c|}
\hline Carbon & $\begin{array}{l}\mathrm{CO}_{2} \\
\mathrm{mg} \mathrm{C} \text { core }^{-1}\end{array}$ & $\begin{array}{l}{ }^{14+15} \mathrm{~N}-\mathrm{N}_{2} \mathrm{O} \\
\mathrm{mg} \mathrm{N} \text { core }\end{array}$ & $\begin{array}{l}{ }^{15} \mathrm{~N}-\mathrm{N}_{2} \mathrm{O} \\
\mathrm{mg} \mathrm{N} \text { core }\end{array}$ & $\begin{array}{l}{ }^{15} \mathrm{~N}-\mathrm{N}_{2} \\
\mathrm{mg} \mathrm{N} \text { core }^{-1}\end{array}$ & ${ }^{15} \mathrm{~N}-\left(\mathrm{N}_{2} \mathrm{O} /\left(\mathrm{N}_{2} \mathrm{O}+\mathrm{N}_{2}\right)\right)$ \\
\hline $0 \mathrm{mg}$ residue- $\mathrm{C}$ (control) & $42.48(2.04) c$ & $0.42(0.14) \mathrm{b}$ & $0.26(0.13) b$ & $2.07(0.39) \mathrm{b}$ & $0.08(0.03)$ \\
\hline $1 \mathrm{mg}$ residue-C & $81.84(4.11) b$ & $1.67(0.28) \mathrm{a}$ & $1.58(0.33) a$ & 7.35 (2.59)a & $0.23(0.05)$ \\
\hline $2 \mathrm{mg}$ residue-C & $150.59(4.43) \mathrm{a}$ & $1.91(0.55) \mathrm{a}$ & $1.65(0.53) \mathrm{a}$ & $6.93(2.30) \mathrm{a}$ & $0.22(0.05)$ \\
\hline
\end{tabular}

Different letters indicate significantly different means across residue treatments $(P<0.05)$.

Values in parentheses are \pm one SEM.
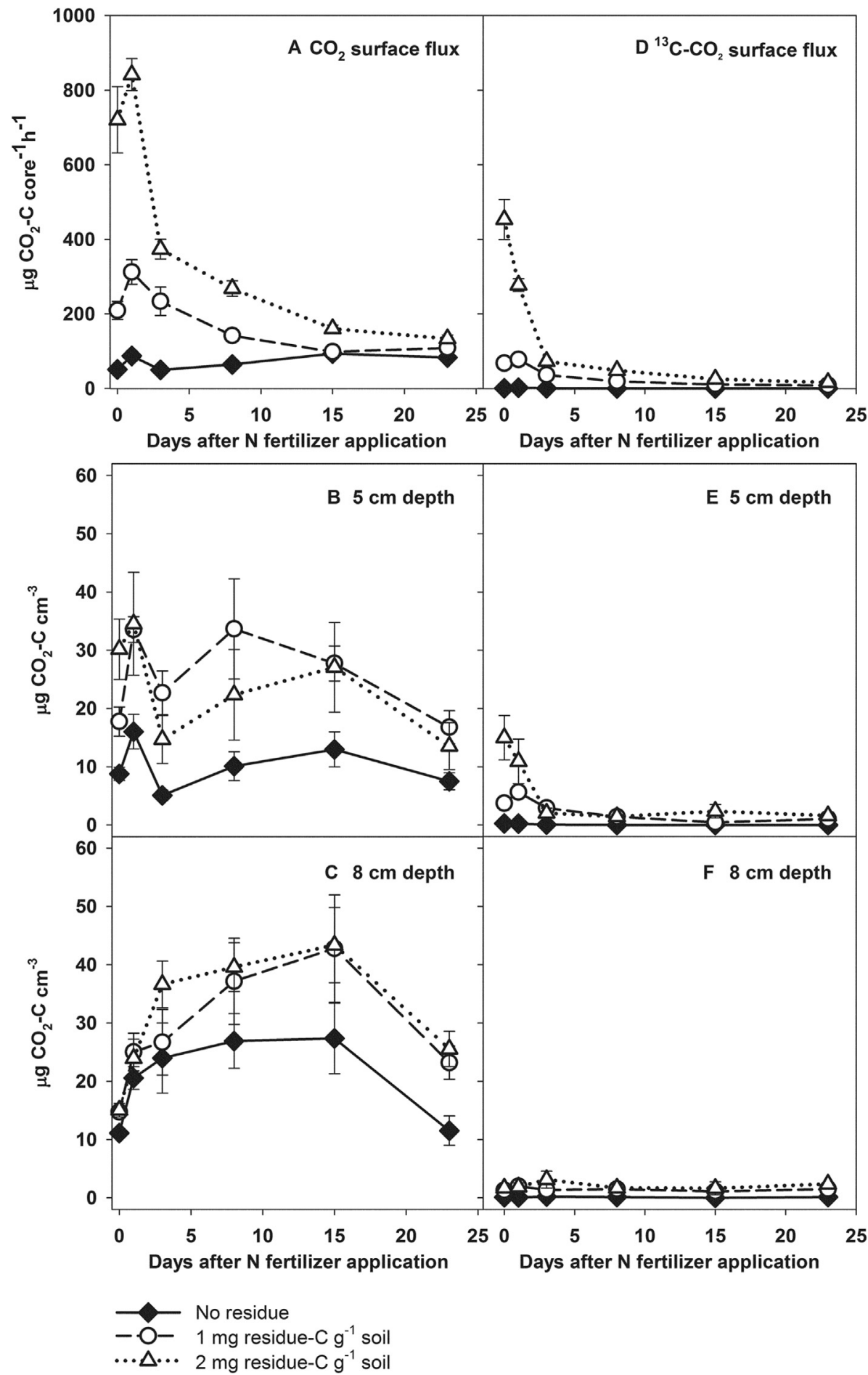

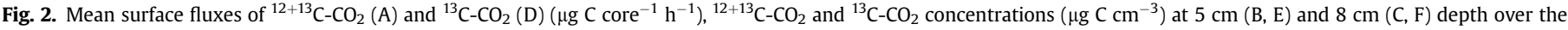
experimental period of 23 days. Error bars represent \pm one SEM. 

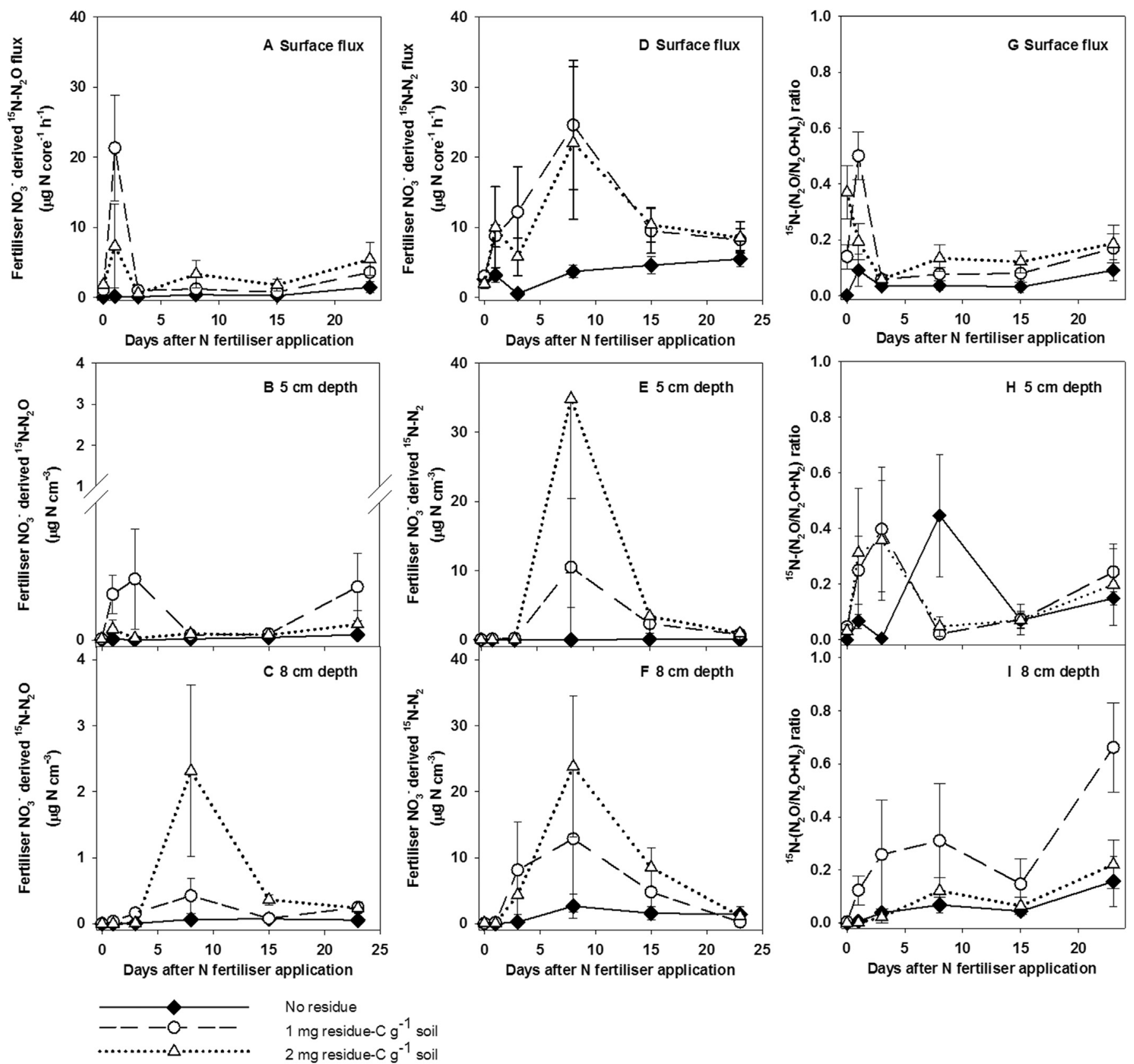

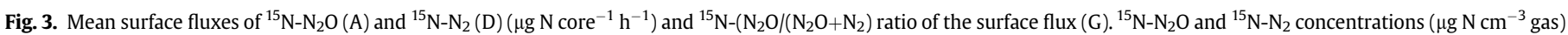
and ratios at $5 \mathrm{~cm}(\mathrm{~B}, \mathrm{E}, \mathrm{H})$ and $8 \mathrm{~cm}(\mathrm{C}, \mathrm{F}, \mathrm{I})$ from the soil surface over the experimental period of 23 days. Error bars represent \pm one SEM.

day.

At $5 \mathrm{~cm}$ depth ${ }^{15} \mathrm{~N}-\mathrm{N}_{2} \mathrm{O}$ concentrations differed significantly between residue treatments $(P<0.01)$. Amendment with $1 \mathrm{mg}$ residue-C resulted in greater ${ }^{15} \mathrm{~N}-\mathrm{N}_{2} \mathrm{O}$ concentrations compared to the control and the $2 \mathrm{mg}$ residue-C treatment $(P<0.05)$ (Fig. 3B). The effect of residue on ${ }^{15} \mathrm{~N}-\mathrm{N}_{2} \mathrm{O}$ concentration at $8 \mathrm{~cm}$ depth depended on the day of measurement (significant interaction between Day x $C, P<0.01$ ) (Fig. 3C). Concentrations differed from the control on day 8 when amended with $2 \mathrm{mg}$ residue- $\mathrm{C}$ and a peak concentration of $2.32 \mu \mathrm{g}{ }^{15} \mathrm{~N}-\mathrm{N}_{2} \mathrm{O} \mathrm{cm} \mathrm{cm}^{-3}$ was measured. When comparing across depths on days of significant surface peaks of fertiliser derived emissions (i.e. day 1 for ${ }^{15} \mathrm{~N}-\mathrm{N}_{2} \mathrm{O}$ and day 8 for ${ }^{15} \mathrm{~N}$ $\mathrm{N}_{2}$, see section 2.4) we found no differences in ${ }^{15} \mathrm{~N}-\mathrm{N}_{2} \mathrm{O}$ concentrations between depths on day 1 . On day $8,{ }^{15} \mathrm{~N}-\mathrm{N}_{2} \mathrm{O}$ concentrations tended to be greater at $8 \mathrm{~cm}$ depth with an average concentration of $0.94 \mu \mathrm{g}$ compared to $0.01 \mu \mathrm{g}{ }^{15} \mathrm{~N}-\mathrm{N}_{2} \mathrm{O} \mathrm{cm}{ }^{-3}$ soil gas at $5 \mathrm{~cm}$ depth $(P=0.053)$.

\section{4. $N_{2}$ fluxes and profile concentrations}

The average daily flux of ${ }^{15} \mathrm{~N}-\mathrm{N}_{2}$ at the soil surface was greater with $1 \mathrm{mg} C$ amendment compared to the control $(P<0.05)$. Interestingly, $2 \mathrm{mg}$ residue- $C$ amendment had a smaller impact on ${ }^{15} \mathrm{~N}-\mathrm{N}_{2}$ fluxes, with emissions differing from neither the control nor from the lower $\mathrm{C}$ amended soil. Averaged over residue treatments, fluxes of $\mathrm{N}_{2}$ were consistently greater on day 8 and onwards compared to day 0 of the experiment $(P<0.001)$ (Fig. 3D).

At both 5 and $8 \mathrm{~cm}$ depth, the effects of residue amendment on 


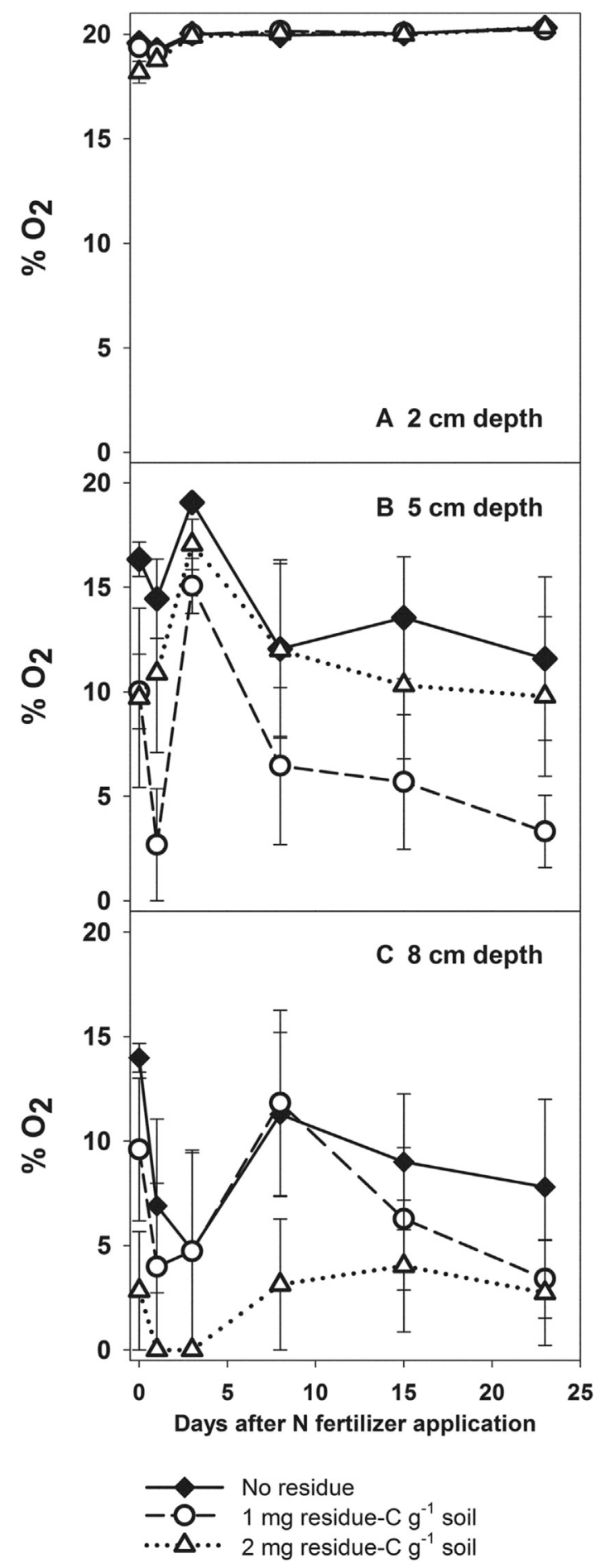

Fig. 4. Oxygen concentrations at $2 \mathrm{~cm}$ (A), $5 \mathrm{~cm}$ (B) and $8 \mathrm{~cm}$ (C) depth of the soil cores amended with 0,1 or $2 \mathrm{mg}$ residue- $\mathrm{C}^{-1}$. Error bars represent \pm one SEM.

\footnotetext{
${ }^{15} \mathrm{~N}-\mathrm{N}_{2}$ concentrations were not significant. However, we observed differences between days with significantly increased ${ }^{15} \mathrm{~N}-\mathrm{N}_{2}$ concentrations at both 5 and $8 \mathrm{~cm}$ depths on days 8 and 15 when compared to ${ }^{15} \mathrm{~N}-\mathrm{N}_{2}$ concentrations at the start of the experiment ( $P=0.001$ and $P<0.001$, respectively) (Fig. 3E,F). Average concentrations on day 1 , when surface ${ }^{15} \mathrm{~N}-\mathrm{N}_{2} \mathrm{O}$ concentrations peaked, were greater at $8 \mathrm{~cm}$ compared to $5 \mathrm{~cm}$ depth $(P=0.001)$. There was no difference in ${ }^{15} \mathrm{~N}-\mathrm{N}_{2}$ concentrations between depths on day
}

8 when the ${ }^{15} \mathrm{~N}-\mathrm{N}_{2}$ surface flux peaked.

The ${ }^{15} \mathrm{~N}-\left(\mathrm{N}_{2} \mathrm{O} /\left(\mathrm{N}_{2} \mathrm{O}+\mathrm{N}_{2}\right)\right)$ ratio of fluxes was significantly different between residue treatments depending on day (significant interaction between Day x C, $P<0.001$ ) (Fig. 3G). It was significantly greater on day 0 when amended with $2 \mathrm{mg}$ residue-C $\mathrm{g}^{-1}$ soil and on day 1 when amended with $1 \mathrm{mg}$ residue- $\mathrm{C}^{-1}$ soil compared to the control soil on the respective days $(P<0.001)$. At $5 \mathrm{~cm}$ depth the ${ }^{15} \mathrm{~N}-\left(\mathrm{N}_{2} \mathrm{O}\right.$-to- $\left.\mathrm{N}_{2}\right)$ ratio was neither significantly different between $\mathrm{C}$ treatments nor between days (Fig. $3 \mathrm{H}$ ) with no significant interaction between the factors. At $8 \mathrm{~cm}$ depth, the ratio was greater on day 23 compared to all other days $(P<0.001)$ (Fig. 3I).

\section{5. $\mathrm{O}_{2}$ profile concentrations}

Oxygen concentrations decreased with soil depth with an average concentration of $11.1 \pm 0.8 \%$ at $5 \mathrm{~cm}$ depth and $5.9 \pm 0.8 \%$ at $8 \mathrm{~cm}$ depth of the soil core. At $5 \mathrm{~cm}$ depth we measured a significantly greater $\mathrm{O}_{2}$ concentration three days after residue-C and $\mathrm{N}$ application compared to all other days $(P<0.001)$ but residue treatments did not affect $\mathrm{O}_{2}$ at that depth (Fig. 4B). At $8 \mathrm{~cm}$ depth, $\mathrm{O}_{2}$ concentration differed between residue-C treatments $(P<0.001)$ with an average of $6.8 \%$ less $\mathrm{O}_{2}$ when $2 \mathrm{mg}$ of residue- $\mathrm{C}$ were amended compared to the control and the $1 \mathrm{mg}$ residue- $C$ treatment (Fig. 4C). Interaction terms between the factors Day and $C$ were not significant at 5 and $8 \mathrm{~cm}$ depth.

\subsection{Biochemical soil properties}

In the topsoil, nitrate concentrations were significantly different between days depending on residue treatment (significant interaction between $C \times$ Day, $P<0.05$ ). Nitrate increased significantly from day 0 to day 23 with $2 \mathrm{mg}$ of residue-C amended and from day $0-15$ with $1 \mathrm{mg}$ residue-C amended (Fig. 5A) $(P<0.05)$. After the surface application of $\mathrm{N}$ fertiliser, $\mathrm{NO}_{3}^{-}-\mathrm{N}$ concentrations at 5 and $8 \mathrm{~cm}$ depth increased throughout the experiment (Fig. 5B and C). Maximum concentrations of nitrate- $\mathrm{N}$ at $2 \mathrm{~cm}, 5 \mathrm{~cm}$ and $8 \mathrm{~cm}$ depth were 238,138 and $82 \mu \mathrm{g} \mathrm{N} \mathrm{g}{ }^{-1}$ soil averaged across residue-C treatments, respectively (data not shown). Interaction effects between $\mathrm{C}$ and Day on ${ }^{15} \mathrm{~N}-\mathrm{NO}_{3}^{-}$concentrations were significant at all three soil depths (all $P<0.001$ ). However, multiple comparisons of ${ }^{15} \mathrm{~N}_{-} \mathrm{NO}_{3}^{-}$concentrations for each soil depth showed no significant differences between residue- $C$ treatments on any of the extraction days (Fig. 5D, E, F).

Microbial biomass at $2 \mathrm{~cm}$ depth differed greatly between residue treatments and days of measurement with significant interaction between the factors $(P<0.001)$. At 5 and $8 \mathrm{~cm}$ depths microbial biomass remained at concentrations similar to the initial biomass of $291.6 \mu \mathrm{g} \mathrm{C} \mathrm{g}^{-1}$ soil (Supplementary Fig. 1). Similarly, the interaction between factors was significant for DOC concentrations at $2 \mathrm{~cm}$ depth $(P<0.001)$, and only different between days at 5 or $8 \mathrm{~cm}$ depth $(P<0.001$ for both) (Supplementary Fig. 1$)$.

\subsection{Relationships between variables}

On day 1 when ${ }^{15} \mathrm{~N}-\mathrm{N}_{2} \mathrm{O}$ fluxes peaked, the fertiliser nitrate derived denitrification surface flux from the carbon amended soils was negatively related to total $\mathrm{CO}_{2}\left(\mathrm{R}^{2}=0.45, P<0.001\right),{ }^{12} \mathrm{C}_{-} \mathrm{CO}_{2}$ $\left(\mathrm{R}^{2}=0.56, P<0.001\right)$ and more weakly related to ${ }^{13} \mathrm{C}-\mathrm{CO}_{2}$ $\left(\mathrm{R}^{2}=0.18, P<0.05\right)$ surface fluxes (Fig. 6). When divided into residue-C treatments the relationship between ${ }^{12} \mathrm{C}_{-}-\mathrm{CO}_{2}$ and total denitrification (rate of $\mathrm{N}_{2} \mathrm{O}+\mathrm{N}_{2}$ ) was stronger with $2 \mathrm{mg}$ residue-C $\left(\mathrm{R}^{2}=0.50, P<0.05\right)$ than with $1 \mathrm{mg}$ residue-C treatment $\left(\mathrm{R}^{2}=0.30\right.$, $P<0.05)$. For both residue-C treatments separately, the relationship between ${ }^{13} \mathrm{C}-\mathrm{CO}_{2}$ and total denitrification was not significant. 
At depth, fertiliser nitrate derived denitrification (the sum of ${ }^{15} \mathrm{~N}-\mathrm{N}_{2} \mathrm{O}$ and ${ }^{15} \mathrm{~N}-\mathrm{N}_{2}$ concentrations) was positively related to ${ }^{12+13} \mathrm{C}^{-}-\mathrm{CO}_{2}\left(\mathrm{R}^{2}=0.52, P<0.001\right)$ and when separated into depths, this relationship was stronger at $8 \mathrm{~cm}$ depth $\left(R^{2}=0.59, P<0.001\right)$ compared to $5 \mathrm{~cm}$ depth $\left(\mathrm{R}^{2}=0.36, P<0.001\right)$ (Fig. 7). While the relationship of the profile concentrations of fertiliser nitrate derived denitrification with ${ }^{13} \mathrm{C}_{-}-\mathrm{CO}_{2}$ was not significant, it was significant and positive with SOM-derived ${ }^{12} \mathrm{C}^{-} \mathrm{CO}_{2}\left(\mathrm{R}^{2}=0.57\right.$,

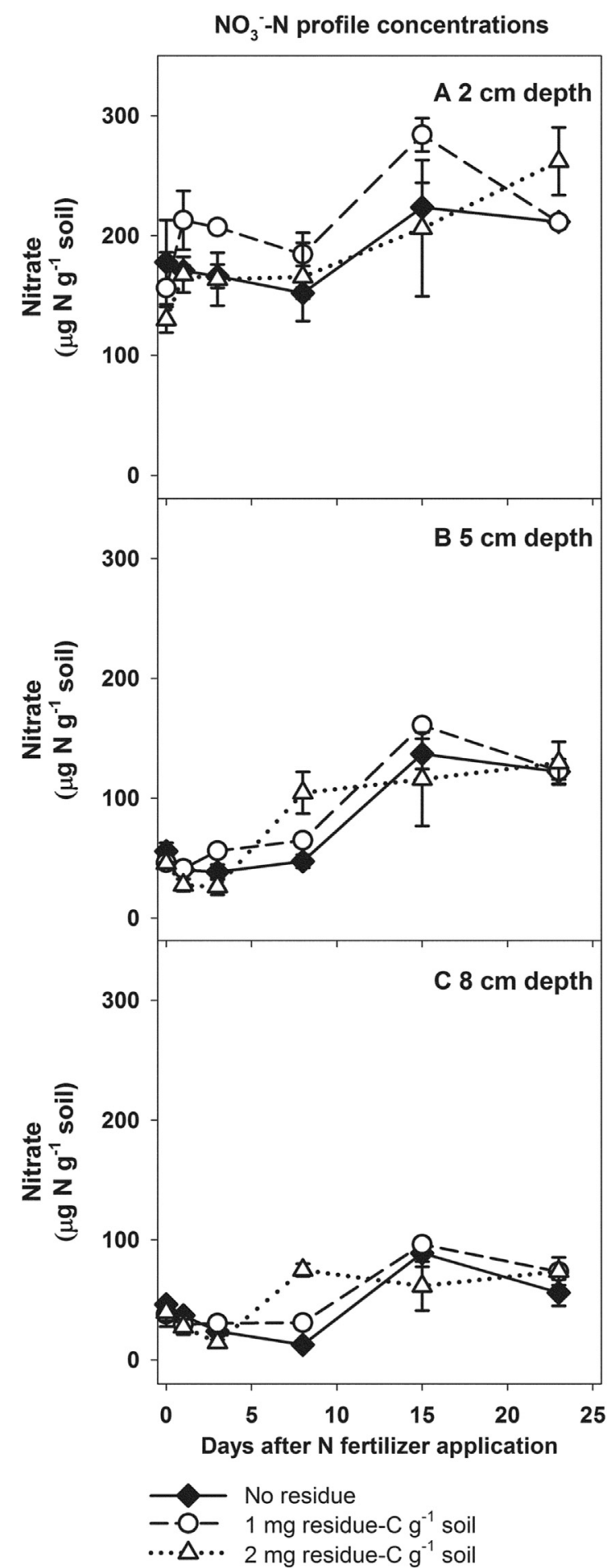

$P<0.001)$. As for ${ }^{12+13} \mathrm{C}-\mathrm{CO}_{2}$, this positive relationship was stronger at $8 \mathrm{~cm}\left(\mathrm{R}^{2}=0.54, P<0.001\right)$ compared to $5 \mathrm{~cm}$ depth $\left(\mathrm{R}^{2}=0.42\right.$, $P<0.001)$.

Fertiliser nitrate derived denitrification was negatively related to $\mathrm{O}_{2}$ concentrations in the whole profile $\left(\mathrm{R}^{2}=0.31, P<0.001\right)$, at $5 \mathrm{~cm}$ depth $\left(\mathrm{R}^{2}=0.39, P<0.001\right)$ and at $8 \mathrm{~cm}$ depth $\left(\mathrm{R}^{2}=0.17\right.$, $P<0.001$ ). Nitrate concentrations were not significantly related to fertiliser nitrate derived denitrification within the soil core.

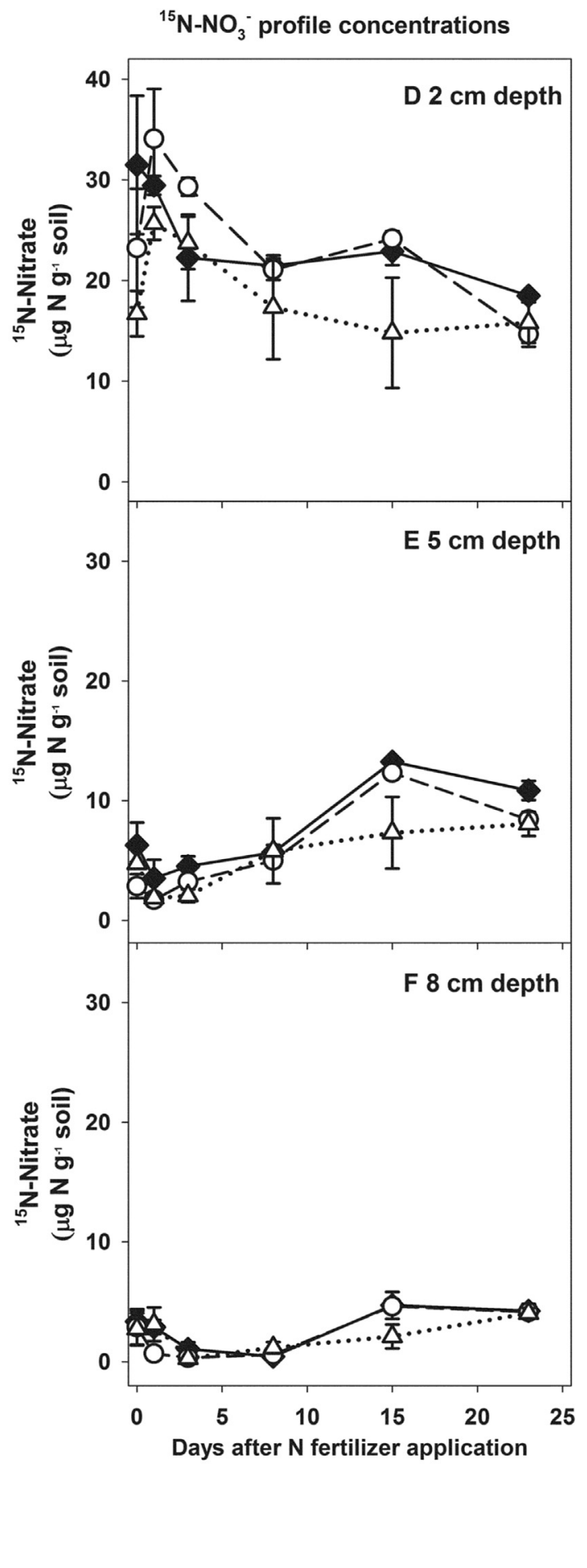

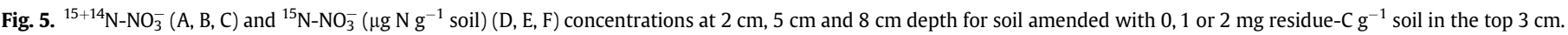
Error bars represent \pm one SEM. 


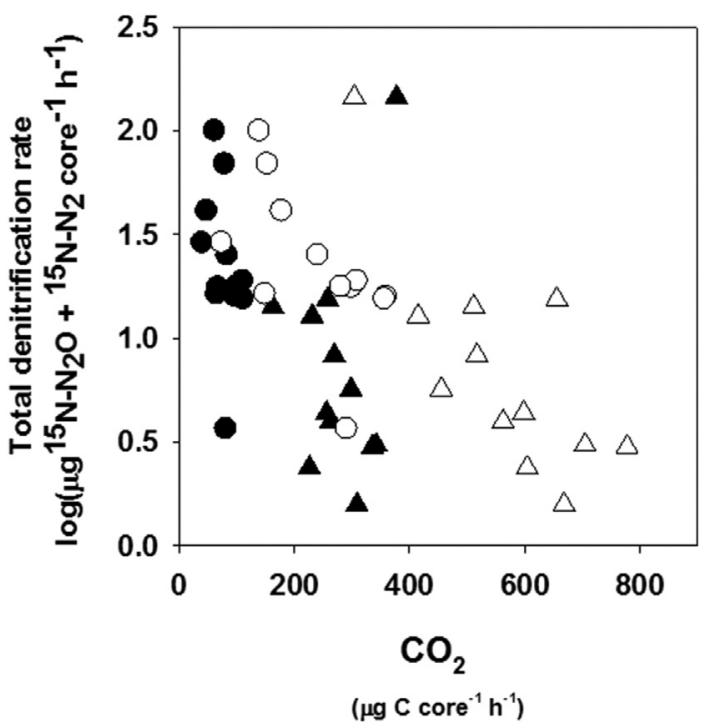

Fig. 6. Relationship between total denitrification rate and source-partitioned $\mathrm{CO}_{2}$ emitted on day 1 from the surface of soils amended with $1 \mathrm{mg}$ residue- $\mathrm{C}$ (circles) and $2 \mathrm{mg}$ residue- $\mathrm{C}$ (triangles). Filled and open symbols represent ${ }^{13} \mathrm{C}_{-} \mathrm{CO}_{2}$ and ${ }^{12} \mathrm{C}_{-} \mathrm{CO}_{2}$ fluxes, respectively.

\section{Discussion}

Using a stable isotope approach combined with soil pore space measurements of gas concentrations at depth we showed two spatially and temporally distinct mechanisms of residue-C affecting denitrification. Next to an immediate stimulatory effect at the soil surface, we measured a second, residue-driven increase of denitrifier activity at depth. Residue-C respiration and oxygen consumption close to the soil surface stimulated denitrification at greater depth indirectly, and resulted in an increased surface flux of $\mathrm{N}_{2}$ rather than $\mathrm{N}_{2} \mathrm{O}$ due to efficient reduction within the soil core.

\subsection{Residue addition and immediate emissions of $\mathrm{N}_{2} \mathrm{O}$ - the immediate effect}

One day after the addition of residue- $\mathrm{C}$ and $\mathrm{N}$ fertiliser we observed a peak surface flux of ${ }^{15} \mathrm{~N}-\mathrm{N}_{2} \mathrm{O}$. The $\mathrm{N}_{2} \mathrm{O}$ peak only occurred in soils to which residue had been applied, likely driven by greater microbial biomass as well as an increased supply of electrons to the denitrification pathway (Giles et al., 2012; Smith and Tiedje, 1979).

The surface $\mathrm{CO}_{2}$ flux indicated rapid mineralisation of the barley residue with greatest rates of $\mathrm{CO}_{2}$ production within three days of its application. This pattern of mineralisation was similar to that generally observed when applying agricultural residues to soil (De Troyer et al., 2011; Redin et al., 2014). Here, this residue-C stimulated heterotrophic activity and growth in the soil layer where it was concentrated and made little to no contribution to $\mathrm{C}$ mineralisation in the soil below the top $3 \mathrm{~cm}$. The ${ }^{13} \mathrm{C}-\mathrm{CO}_{2}$ concentrations at $5 \mathrm{~cm}$ depth in our case were most likely a result of gas diffusion as it has been shown in other studies that residue mineralisation is spatially limited to about $4 \mathrm{~mm}$ around the detritus (Gaillard et al., 1999; Nicolardot et al., 2007). In accordance with that, DOC or microbial biomass $\mathrm{C}$ did not differ between the control and the residue treated soils at both 5 and $8 \mathrm{~cm}$ soil depth in our study, suggesting a limited movement of residue below the layer of incorporation. Hence, on day 1 we did not observe significantly increased concentrations of ${ }^{15} \mathrm{~N}-\mathrm{N}_{2} \mathrm{O}$ at 5 or $8 \mathrm{~cm}$ depth in the residue amended soil cores that could explain the peaking surface fluxes. Residue therefore facilitated, increased rates of $\mathrm{N}_{2} \mathrm{O}$ production in close proximity to the soil surface possibly directly providing a source of $\mathrm{C}$ or by creating anaerobic microsites within the soil surface layer. However, we did not measure increased rates of $\mathrm{N}_{2}$ surface emissions and the soil pore space concentrations of oxygen remained close to atmospheric. The conditions are likely to have promoted nitrate reduction while restricting the expression and activity of the $\mathrm{O}_{2}$ sensitive $\mathrm{N}_{2} \mathrm{O}$ reductase (Weier et al., 1993).

At the soil surface the initial peak of total denitrification, mainly being ${ }^{15} \mathrm{~N}-\mathrm{N}_{2} \mathrm{O}$, was negatively related to $\mathrm{CO}_{2}$ fluxes from residueamended soil. This disagrees with previous findings where $\mathrm{CO}_{2}$ evolution was positively related to total denitrification (Burford and Bremner, 1975; Henderson et al., 2010; Miller et al., 2009; Walvoord et al., 2014). A possible explanation for this unexpected response could be out-competition of denitrifying organisms by the growth of other non-denitrifying heterotrophs at high available C. Immediate net $\mathrm{N}_{2} \mathrm{O}$ fluxes after residue application might thus potentially be driven by interactions within the microbial community triggered by the quantity of newly available $\mathrm{C}$ and $\mathrm{N}$.

\subsection{Residue mineralisation and $\mathrm{N}_{2} \mathrm{O}$ production and reduction - the indirect, delayed effect}

With a delay of 1 week compared to the ${ }^{15} \mathrm{~N}-\mathrm{N}_{2} \mathrm{O}$ emission peak in residue amended soils, the ${ }^{15} \mathrm{~N}-\mathrm{N}_{2}$ surface fluxes peaked, irrespective of whether 1 or $2 \mathrm{mg}$ residue- $\mathrm{C}^{-1}$ soil had been added. Using the acetylene inhibition method Miller et al. (2008) have shown that reduction of $\mathrm{N}_{2} \mathrm{O}$ may not occur immediately after

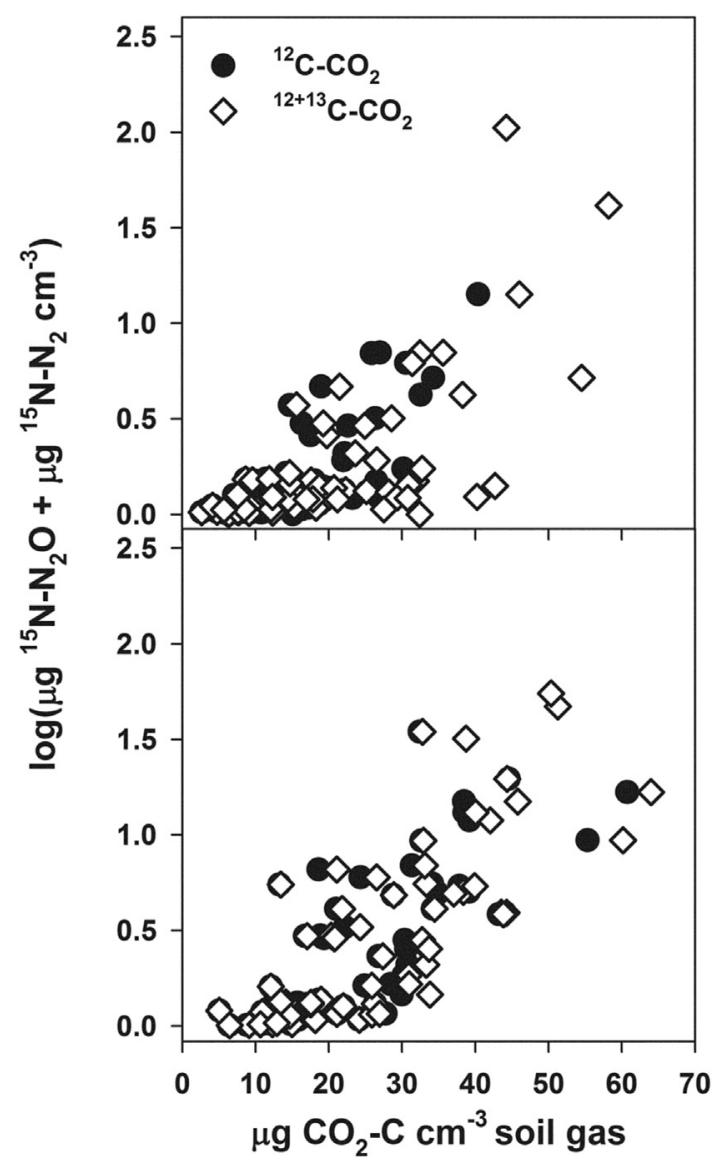

Fig. 7. Relationship between denitrification products and $\mathrm{CO}_{2}$ derived from $\mathrm{SOM}-\mathrm{C}$ $\left.{ }^{12} \mathrm{C}-\mathrm{CO}_{2}\right)$ and with total $\mathrm{CO}_{2}-\mathrm{C}\left({ }^{12+13} \mathrm{C}-\mathrm{CO}_{2}\right)$ at $5 \mathrm{~cm}$ depth (top) and $8 \mathrm{~cm}$ depth (bottom). 
residue- $\mathrm{C}$ and $\mathrm{N}$ fertiliser application. Accordingly, Morley and Baggs (2010) observed a lag of $65 \mathrm{~h}$ with which $\mathrm{N}_{2} \mathrm{O}$ was reduced to $\mathrm{N}_{2}$ following ${ }^{15} \mathrm{~N}-\mathrm{NO}_{3}^{-}$addition to agricultural soil. This has often been associated with the time lag in synthesis of the enzyme $\mathrm{N}_{2} \mathrm{O}$ reductase (Zheng and Doskey, 2016). However, our data provides an additional explanation for $\mathrm{N}_{2}$ emission peaks at the surface which is related to the effect of residue addition within the soil profile.

We observed up to $50 \%$ residue-derived $\mathrm{CO}_{2}$ only on the first day after application at $5 \mathrm{~cm}$ depth, whereas less than $10 \%$ of $\mathrm{CO}_{2}$ in the soil gas was residue-derived throughout the whole experimental period at $8 \mathrm{~cm}$ depth. Yet, we observed that residue addition to the surface increased the concentrations of $\mathrm{N}_{2} \mathrm{O}$ at depth. Corresponding to this increase, the concentration of $\mathrm{N}_{2}$, the product of $\mathrm{N}_{2} \mathrm{O}$ reduction, increased at both $8 \mathrm{~cm}$ and $5 \mathrm{~cm}$ depths. This points at efficient reduction of $\mathrm{N}_{2} \mathrm{O}$ to $\mathrm{N}_{2}$ in the location of its highest concentration and an upward movement finally resulting in surface emission of $\mathrm{N}_{2}$ rather than $\mathrm{N}_{2} \mathrm{O}$.

This, in combination with the negative relationship between the concentrations of total denitrification products with $\mathrm{O}_{2}$ at depth, suggests that the effects of residue addition were of indirect nature. Rather than being directly utilized by denitrifiers as an electron donor, residue-C mineralisation can indirectly deplete $\mathrm{O}_{2}$ at the surface. As a result, the decreased $\mathrm{O}_{2}$ concentrations in the bulk soil at greater depth facilitate the reduction of $\mathrm{N}_{2} \mathrm{O}$ to $\mathrm{N}_{2}$ which in turn lowers surface emission of $\mathrm{N}_{2} \mathrm{O}$. Further, the positive relationship of denitrification products with ${ }^{12} \mathrm{C}-\mathrm{CO}_{2}$ at depth also highlights that soil organic matter derived $\mathrm{C}$ can serve as an electron donor for denitrification in soil. In accordance with our results, a layer of manure $\mathrm{C}$ led to low $\mathrm{O}_{2}$ concentrations below its physical location in a study by Zhu et al. (2015). Anaerobic conditions developed below the manure layer within the first $12 \mathrm{~h}$ and created favourable conditions for denitrification at a distance of several $\mathrm{cm}$ from the mineralisation hotspot. Our findings are also in line with results obtained by Højberg et al. (1994) who measured denitrification on aggregate scale and observed rapid $\mathrm{O}_{2}$ depletion at an aggregate surface following application of a piece of clover leaf that in turn increased $\mathrm{N}_{2} \mathrm{O}$ production and reduction indirectly.

In the field, residue incorporation often occurs simultaneously with mechanical disturbance of the soil, which introduces $\mathrm{O}_{2}$ into the topsoil. The conditions established in this experiment therefore resemble early time effects of surface residue incorporation such as with reduced or minimum tillage. It has previously been established that deeper $\mathrm{N}$ placement in reduced or no till systems can decrease net $\mathrm{N}_{2} \mathrm{O}$ emissions (van Kessel et al., 2013) and our study contributes to the mechanistic understanding of this finding. Our results point to the need for targeted mitigation of hot-spot formation at the soil surface while fostering the completion of denitrification reduction of $\mathrm{N}_{2} \mathrm{O}$ to $\mathrm{N}_{2}$ within the soil profile where reduction efficiency is high. Agricultural management practices should thus consider combinations of residue quality and placement i.e. by tillage operations and/or deep fertiliser placement that maximises the reduction potential of the soil while ensuring optimal plant $\mathrm{N}$ uptake.

\section{Acknowledgements}

This work was supported by a Biotechnology and Biological Sciences Research Council (BB/F017006/1) doctoral training grant awarded to the University of Aberdeen and the Scottish Government Strategic Research Programme. Marianne Kuntz was also supported by funding from the Roland Sutton Trust at SRUC. We would like to acknowledge the excellent technical help of Vicky Munro and Luke Harrold in the analysis of isotope samples. We are grateful to Robin Walker and the SRUC field team for maintenance of the Woodlands Field long-term crop rotations experiments at the
Craibstone Estate.

\section{Appendix A. Supplementary data}

Supplementary data related to this article can be found at http:// dx.doi.org/10.1016/j.soilbio.2016.09.012.

\section{References}

Baggs, E.M., Rees, R.M., Smith, K.A., Vinten, A.J.A., 2000. Nitrous oxide emission from soils after incorporating crop residues. Soil Use and Management 16, 82-87.

Ball, B.C., 2013. Soil structure and greenhouse gas emissions: a synthesis of 20 years of experimentation. European Journal of Soil Science 64, 357-373. http:/ dx.doi.org/10.1111/ejss.12013.

Burford, J.R., Bremner, J.M., 1975. Relationships between the denitrification capacities of soils and total, water-soluble and readily decomposable soil organic matter. Soil Biology and Biochemistry 7, 389-394. http://dx.doi.org/10.1016/ 0038-0717(75)90055-3.

Chen, H., Li, X., Hu, F., Shi, W., 2013. Soil nitrous oxide emissions following crop residue addition: a meta-analysis. Global Change Biology 19, 2956-2964. http://dx.doi.org/10.1111/gcb.12274.

De Troyer, I., Amery, F., Van Moorleghem, C., Smolders, E., Merckx, R., 2011. Tracing the source and fate of dissolved organic matter in soil after incorporation of a ${ }^{13} \mathrm{C}$ labelled residue: a batch incubation study. Soil Biology and Biochemistry 43, 513-519. http://dx.doi.org/10.1016/j.soilbio.2010.11.016.

Frimpong, K.A., Baggs, E.M., 2010. Do combined applications of crop residues and inorganic fertiliser lower emission of $\mathrm{N}_{2} \mathrm{O}$ from soil? Soil Use and Management 26, 412-424. http://dx.doi.org/10.1111/j.1475-2743.2010.00293.x.

Gaillard, V., Chenu, C., Recous, S., Richard, G., 1999. Carbon, nitrogen and microbial gradients induced by plant residues decomposing in soil. European Journal of Soil Science 50, 567-578. http://dx.doi.org/10.1046/j.1365-2389.1999.00266.x.

Giles, M., Morley, N.J., Baggs, E.M., Daniell, T.J., 2012. Soil nitrate reducing processes - drivers, mechanisms for spatial variation, and significance for nitrous oxide production. Frontiers in Microbiology 3, 1-16. http://dx.doi.org/10.3389/ fmicb.2012.00407.

Gillam, K.M., Zebarth, B.J., Burton, D.L., 2008. Nitrous oxide emissions from denitrification and the partitioning of gaseous losses as affected by nitrate and carbon addition and soil aeration. Canadian Journal of Soil Science 88, 133-143. http://dx.doi.org/10.4141/CJSS06005.

Henderson, S.L., Dandie, C.E., Patten, C.L., Zebarth, B.J., Burton, D.L., Trevors, J.T. Goyer, C., 2010. Changes in denitrifier abundance, denitrification gene mRNA levels, nitrous oxide emissions, and denitrification in anoxic soil microcosms amended with glucose and plant residues. Applied and Environmental Microbiology 76, 2155-2164. http://dx.doi.org/10.1128/AEM.02993-09.

Højberg, O., Revsbech, N.P., Tiedje, J.M., 1994. Denitrification in soil aggregates analyzed with microsensors for nitrous oxide and oxygen. Soil Science Society of America Journal 58, 1691. http://dx.doi.org/10.2136/ sssaj1994.03615995005800060016x.

Huang, Y., Zou, J., Zheng, X., Wang, Y., Xu, X., 2004. Nitrous oxide emissions as influenced by amendment of plant residues with different C: $\mathrm{N}$ ratios. Soil Biology and Biochemistry 36, 973-981. http://dx.doi.org/10.1016/ j.soilbio.2004.02.009.

Jahangir, M.M.R., Khalil, M.I., Johnston, P., Cardenas, L.M., Hatch, D.J., Butler, M., Barrett, M., O'flaherty, V., Richards, K.G., 2012. Denitrification potential in subsoils: a mechanism to reduce nitrate leaching to groundwater. Agriculture Ecosystems \& Environment 147, 13-23. http://dx.doi.org/10.1016/ j.agee.2011.04.015.

Jarecke, K.M., Loecke, T.D., Burgin, A.J., 2016. Coupled soil oxygen and greenhouse gas dynamics under variable hydrology. Soil Biology and Biochemistry 95, 164-172. http://dx.doi.org/10.1016/j.soilbio.2015.12.018.

Joergensen, R.G., 1996. The fumigation-extraction method to estimate soil microbial biomass: calibration of the kEC value. Soil Biology and Biochemistry 28, 25-31. http://dx.doi.org/10.1016/0038-0717(95)00102-6.

Li, X., Sørensen, P., Olesen, J.E., Petersen, S.O., 2016. Evidence for denitrification as main source of $\mathrm{N}_{2} \mathrm{O}$ emission from residue-amended soil. Soil Biology and Biochemistry 92, 153-160. http://dx.doi.org/10.1016/j.soilbio.2015.10.008.

McCarty, G.W., Shelton, D.R., Sadeghi, a. M., 1999. Influence of air porosity on distribution of gases in soil under assay for denitrification. Biology and Fertility of Soils 30, 173-178. http://dx.doi.org/10.1007/s003740050605.

Millar, N., Baggs, E.M., 2005. Relationships between $\mathrm{N}_{2} \mathrm{O}$ emissions and watersoluble $\mathrm{C}$ and $\mathrm{N}$ contents of agroforestry residues after their addition to soil Soil Biology and Biochemistry 37, 605-608. http://dx.doi.org/10.1016/ j.soilbio.2004.08.016.

Millar, N., Baggs, E.M., 2004. Chemical composition, or quality, of agroforestry residues influences $\mathrm{N}_{2} \mathrm{O}$ emissions after their addition to soil. Soil Biology and Biochemistry 36, 935-943. http://dx.doi.org/10.1016/j.soilbio.2004.02.008.

Miller, M.N., Dandie, C.E., Zebarth, B.J., Burton, D.L., Goyer, C., Trevors, J.T., 2012. Influence of carbon amendments on soil denitrifier abundance in soil microcosms. Geoderma 170, 48-55. http://dx.doi.org/10.1016/ j.geoderma.2011.11.022.

Miller, M.N., Zebarth, B.J., Dandie, C.E., Burton, D.L., Goyer, C., Trevors, J.T., 2009. Influence of liquid manure on soil denitrifier abundance, denitrification, and 
nitrous oxide emissions. Soil Science Society of America Journal 73, 760. http:// dx.doi.org/10.2136/sssaj2008.0059.

Miller, M.N., Zebarth, B.J., Dandie, C.E., Burton, D.L., Goyer, C., Trevors, J.T., 2008 Crop residue influence on denitrification, $\mathrm{N}_{2} \mathrm{O}$ emissions and denitrifier community abundance in soil. Soil Biology and Biochemistry 40, 2553-2562. http:/ dx.doi.org/10.1016/j.soilbio.2008.06.024.

Morley, N.J., Baggs, E.M., 2010. Carbon and oxygen controls on $\mathrm{N}_{2} \mathrm{O}$ and $\mathrm{N}_{2}$ production during nitrate reduction. Soil Biology and Biochemistry 42, 1864-1871. http://dx.doi.org/10.1016/j.soilbio.2010.07.008.

Morley, N.J., Richardson, D.J., Baggs, E.M., 2014. Substrate induced denitrification over or under estimates shifts in soil $\mathrm{N}_{2} / \mathrm{N}_{2} \mathrm{O}$ ratios. Plos One 9 , e108144. http:/ dx.doi.org/10.1371/journal.pone.0108144.

Muhammad, W., Vaughan, S.M., Dalal, R.C., Menzies, N.W., 2010. Crop residues and fertilizer nitrogen influence residue decomposition and nitrous oxide emission from a Vertisol. Biology and Fertility of Soils 47, 15-23. http://dx.doi.org/ 10.1007/s00374-010-0497-1.

Nicolardot, B., Bouziri, L., Bastian, F., Ranjard, L., 2007. A microcosm experiment to evaluate the influence of location and quality of plant residues on residue decomposition and genetic structure of soil microbial communities. Soil Biology and Biochemistry 39, 1631-1644. http://dx.doi.org/10.1016 j.soilbio.2007.01.012.

R Development Core Team, 2015. R: a Language and Environment for Statistica Computing. R Foundation for Statistical Computing, R Foundation for Statistical Computing. http://dx.doi.org/10.1007/978-3-540-74686-7.

Redin, M., Recous, S., Aita, C., Dietrich, G., Skolaude, A.C., Ludke, W.H., Schmatz, R. Giacomini, S.J., 2014. How the chemical composition and heterogeneity of crop residue mixtures decomposing at the soil surface affects $\mathrm{C}$ and $\mathrm{N}$ mineralisation. Soil Biology and Biochemistry 78, 65-75. http://dx.doi.org/10.1016/ j.soilbio.2014.07.014.

Senbayram, M., Chen, R, Budai, a., Bakken, L, Dittert, K, 2012. $\mathrm{N}_{2} \mathrm{O}$ emission and the $\mathrm{N}_{2} \mathrm{O} /\left(\mathrm{N}_{2} \mathrm{O}+\mathrm{N}_{2}\right)$ product ratio of denitrification as controlled by available carbon substrates and nitrate concentrations. Agriculture, Ecosystems and Environment 147, 4-12. http://dx.doi.org/10.1016/j.agee.2011.06.022.

Smith, M.S., Tiedje, J.M., 1979. Phases of denitrification following oxygen depletion in soil. Soil Biology and Biochemistry 11, 261-267. http://dx.doi.org/10.1016/ 0038-0717(79)90071-3.

Soong, J.L., Reuss, D., Pinney, C., Boyack, T., Haddix, M.L., Stewart, C.E., Cotrufo, M.F.
2014. Design and operation of a continuous ${ }^{13} \mathrm{C}$ and ${ }^{15} \mathrm{~N}$ labeling chamber for uniform or differential, metabolic and structural, plant isotope labeling. Journal of Visualized Experiments : JoVE e51117. http://dx.doi.org/10.3791/51117.

Stark, J.M., Hart, S.C., 1996. Diffusion technique for preparing salt solutions, Kjeldahl digests, and persulfate digests for nitrogen-15 analysis. Soil Science Society of America Journal. sssaj1996.03615995006000060033x

Thangarajan, R., Bolan, N.S., Tian, G., Naidu, R., Kunhikrishnan, A., 2013. Role of organic amendment application on greenhouse gas emission from soil. Science of the Total Environment 465, 72-96. http://dx.doi.org/10.1016/ j.scitotenv.2013.01.031.

Trinsoutrot, I., Recous, S., Bentz, B., Lineres, M., Cheneby, D., Nicolardot, B., 2000. Biochemical quality of crop residues and carbon and nitrogen mineralization kinetics under nonlimiting nitrogen conditions. Soil Science Society of American Journal 64, 918-926.

van Kessel, C., Venterea, R., Six, J., Adviento-Borbe, M.A., Linquist, B., van Groenigen, K.J., 2013. Climate, duration, and $\mathrm{N}$ placement determine $\mathrm{N}_{2} \mathrm{O}$ emissions in reduced tillage systems: a meta-analysis. Global Change Biology 19, 33-44. http://dx.doi.org/10.1111/j.1365-2486.2012.02779.x.

Vance, E.D., Brookes, P.C., Jenkinson, D.S., 1987. An extraction method for measuring soil microbial biomass C. Soil Biology and Biochemistry 19, 703-707. http:// dx.doi.org/10.1016/0038-0717(87)90052-6.

Walvoord, M. a., Andraski, B. Green, C. T, Stonestrom, D. a., Striegl, R.G, 2014 Field-scale sulfur hexafluoride tracer experiment to understand long distance gas transport in the deep unsaturated zone. Vadose Zone Journal 13. http:// dx.doi.org/10.2136/vzj2014.04.0045, 0 .

Weier, K.L., Doran, J.W., Power, J.F., Walters, D.T., 1993. Denitrification and the $\mathrm{N}_{2}$ to $\mathrm{N}_{2} \mathrm{O}$ ratio as affected by soil water, available $\mathrm{C}$ and $\mathrm{NO}_{3}^{-}$. Soil Science Society of America Journal 75, 6-72.

Zheng, J., Doskey, P.V., 2016. Simulated rainfall on agricultural soil reveals enzymatic regulation of short-term nitrous oxide profiles in soil gas and emissions from the surface. Biogeochemistry. http://dx.doi.org/10.1007/s10533-016-0210-z.

Zhu, K., Bruun, S., Larsen, M., Glud, R.N., Jensen, L.S., 2015. Heterogeneity of $\mathrm{O}_{2}$ dynamics in soil amended with animal manure and implications for greenhouse gas emissions. Soil Biology and Biochemistry 84, 96-106. http:// dx.doi.org/10.1016/j.soilbio.2015.02.012. 